\title{
Environmental Geochemical Assessment of Ogbagha River Sediments in Okpella Area of Edo State, Nigeria
}

\author{
${ }^{1 *}$ OBAJE, SO; ${ }^{1}$ ADELOWO, SA \\ ${ }^{1 *}$ Department of Earth Sciences, Faculty of Science, Adekunle Ajasin University, P.M.B. 001, Akungba-Akoko, Ondo State, Nigeria \\ *Corresponding Author Email: solomon.obaje@aaua.edu.ng,isolobaje1@gmail.com,Tel: +2347061389208
}

\begin{abstract}
The main aim of this paper is the environmental geochemical assessment of Ogbagha river sediments to ascertain the level of their pollution. The study area lies between latitude $7^{\circ} 14^{\prime} \mathrm{N}$ and $7^{\circ} 22^{\prime} \mathrm{N}$ and longitude $6^{\circ} 15^{\prime} \mathrm{E}$ and $6^{\circ} 23^{\prime} \mathrm{E}$ in Okpella area of Edo State, Nigeria. Major and trace elements in the six composite samples collected were analysed using Epsilon-5 x-ray fluorescence model (pAnalytical). $\mathrm{SiO}_{2}$ values range from 71.4-81.61 wt. \% with mean of 75.71 wt \%, while $\mathrm{Al}_{2} \mathrm{O}_{3}$ values range from 7.01-12.97 wt. \% with mean values of 11.56 wt. \%.The other major oxides are below 7.00 wt. \%. $\mathrm{SiO}_{2}$ and $\mathrm{Al}_{2} \mathrm{O}_{3}$ wt. \% values are indicative of felsic source rock. The mean concentration values of $\mathrm{Zr}(1,830.55 \mathrm{ppm}), \mathrm{Ba}(1,416.00 \mathrm{ppm})$ and $\mathrm{Cu}(77.17 \mathrm{ppm})$ are higher than their crustal baseline values. Conversely, Sr (295.00 ppm), In (106.00 ppm), As (14.83 ppm), Cr (8.53 $\mathrm{ppm})$, Co $(7.00 \mathrm{ppm}), \mathrm{Pb}(13.33 \mathrm{ppm})$ have lower average concentrations than their crustal baseline average concentrations. Chemical index of alteration values for the samples also pointed to felsic source rock(s). The index of geoaccumulation values of $\mathrm{Sb}, \mathrm{In}, \mathrm{Zr}$ is indicative of serious environmental geochemical concern in the study area. However, potentially toxic elements such as $\mathrm{Cu}, \mathrm{Cr}, \mathrm{Co}, \mathrm{Pb}$, etc. are below the pollution baseline. It is recommended that standard environmental remediation measures should be taken to mitigate the pollution impact of $\mathrm{In}, \mathrm{Sb}$ and $\mathrm{Zr}$ in the study area.
\end{abstract}

\section{DOI:https://dx.doi.org/10.4314/jasem.v24i2.21}

Copyright: Copyright () 2020 Obaje and Adelowo. This is an open access article distributed under the Creative Commons Attribution License (CCL), which permits unrestricted use, distribution, and reproduction in any medium, provided the original work is properly cited.

Dates: Received: 16 November 2019; Revised: 11 January 2020; Accepted: 22 February 2020

Keywords: Ogbagha-Okpella, environmental geochemistry, enrichment ratios, geoaccumulation index

Stream sediments are useful for regional geochemical surveys because they are sourced from upstream lithology. They are useful indicators of source of anomalous concentrations, mineralogy and/or anthropogenic input into near surface soil and water bodies (Kautsky and Bolviken, 1986; Reid, 1993; Atsuyuki et al., 2005).The environmental and health implications of potentially toxic elements (PTE) in mining environment, especially in artisanal mining areas have been studied and published (Waziri, 2014; Obaje et al., 2015, 2019).

Geology of the Area: The study area is situated in the Southwest Nigerian Precambrian Basement Complex. The Basement Complex of Nigeria has four noticeable major rock units, namely: MigmatiteGneiss-Quartzite Complex, Schist belts, Pan-African Granitoids, and undeformed acid and basic dykes (Dada, 2006; Ogunyele et al., 2018; Obaje et al., 2019). The Nigerian Basement Complex was affected by the Pan-African $(600 \pm 150 \mathrm{Ma})$ orogeny and it occupies the reactivated region which resulted from plate collision between the passive continental margin of the West African craton and the active Pharusian continental margin (Burke and Dewey,
1972). The dominant lithologic units in Ogbagha river area are schist, calc-gneiss, marble, and pegmatite and granite gneiss.

The aim of this paper is to present the result of the assessment of the pollution index level of potentially toxic elements (PTE) in Ogbagha river sediments in Okpella.

\section{MATERIALS AND METHODS}

Location map, plastic samplers, plastic panning bowls, set of sieves, global positioning system (GPS), digital camera, Kraft envelops, nylon bags, plastic hand gloves, field notebook, permanent markers and rubber boots are the materials used in the fieldwork for data acquisition. For the laboratory operation, weighing balance (model: ScoutPro SPU601 S/N7123270179), brush, set of sieves, sieves shaker (STSJ-4 digital high frequency sieves shaker: S/N100064) and cardboard were materials used. The fieldwork involved the collection of Ogbagha river sediments and the recording of the geographical coordinates of the sediments sampling points using GPS and the other field data. Six composite samples of stream sediments were taken at depths of $1.19-2 \mathrm{~m}$ with the aid of plastic sampler and wet sieved and 
packed into labelled brown Kraft envelopes which were sun dried at the field base camp before they were transported to the laboratory. At the Geology Laboratory of Adekunle Ajasin University, AkungbaAkoko, Ondo State, Southwest Nigeria the samples were further treated. $10 \mathrm{~g}$ taken from $63 \mu \mathrm{m}$ fractions of the six samples were taken to the National Geochemical Laboratory of the Nigerian Geological Survey Agency located in Kaduna, North-western Nigeria for X-ray fluorescence (XRF) spectrometric analysis. The samples were crushed to less than 63 microns with the aid of a Tema vibrating mill and then they were sieved to $60 \mu \mathrm{m}$. The samples were pulverised and then dried in an oven at $110{ }^{\circ} \mathrm{C}$ for 24 hours to remove their moisture content and thereafter they were converted to beads for major elemental analysis expressed in oxide weight percent. Furthermore, 5 grams of the dried samples were weighed in the silica crucible and then ignited in the furnace at $1,000{ }^{0} \mathrm{C}$ for 2 to 3 hours to calcinate the impurities in the sample powder. Thereafter, the samples were removed from the furnace and cooled to room temperature using desiccators. The ignited sample powders were weighed again to determine the weight of calcinated impurities such as $\mathrm{H}_{2} \mathrm{O}^{-}, \mathrm{H}_{2} \mathrm{O}^{+}$ and $\mathrm{CO}_{2} .1$ gram of each of the stored ignited sample powder and precisely 5 times of flux (x-ray fluxtype) $66 \%: 34 \% \quad(66 \%$ lithium tetraborate: $34 \%$ lithium metaborate) were added to lower the vitrification temperature. The mixture was weighed and properly mixed in a Platinum dish and then placed in pre-set furnace (Eggon-2 automatic fuse bead maker) at $1,500{ }^{\circ} \mathrm{C}$ for 10 minutes to make into a glass bead. The glass bead produced was labelled and placed into the computerised XRF (Epsilon-5 pAnalytical model) to analyse the concentrations of the major oxide in weight percentages. The trace elemental analysis was performed using compressed powder pellets prepared by weighing 3 grams of oven-dried samples and 3 grams flux (cellulose powder) added as a binder and dispersive agent and they were shaken in small plastic containers for 12 minutes. The mixtures were compressed using pressure of $1,500 \mathrm{kgm}^{-2}$ using manual and electronic compressors. The pellets were fed to the computer programmed $\mathrm{x}$-ray fluorescence spectrometer to analyse the trace elements in part per million (ppm).

\section{RESULTS AND DISCUSSION}

Geochemical Analysis Result: Tables 1-2 present the results of major oxides in weight percentages and trace elements in ppm, while Table 3 presented values of Tables 1-2 in comparison to published upper crust concentrations in wt. $\%$ and parts per million (ppm). Figures 1-2 show the bar chart plots of the mean concentration of the major oxides in weight percentages and the mean concentration of trace elements in ppm for the samples from the study area. Table 4 shows the chemical index of alteration, while Table 5 shows the enrichment ratios for the samples from the study area, and Table 6 presents the index of geoaccumulation $\left(\mathrm{I}_{\mathrm{geo}}\right)$. Lastly, Table 7 indicates the class interpretation of the index of geoaccumulation $\left(I_{\text {geo }}\right)$ of trace elements after Muller (1969).

Chemical Index of Alteration (CIA): Chemical index of alteration (CIA) (Nesbitt and Young, 1982) is used to measure the degree of weathering and computed using the equation,

$$
\mathrm{CIA}=\left[\left(\left(\mathrm{Al}_{2} \mathrm{O}_{3} /\left(\mathrm{Al}_{2} \mathrm{O}_{3}+\mathrm{CaO}+\mathrm{Na}_{2} \mathrm{O}+\mathrm{K}_{2} \mathrm{O}\right)\right)\right) \times 100\right]
$$

Elements Enrichment Ratios: Element enrichment ratios were calculated in order to assess the extent of enrichment and trace elements and/or depletion of trace elements in the study area. The enrichment ratios (ER) are calculated from the formula; $\mathrm{ER}=$ $\mathrm{C}_{\mathrm{n}} / \mathrm{B}_{\mathrm{n}}$ where $\mathrm{Cn}$ is the sample concentration, while $\mathrm{B}_{\mathrm{n}}$ is the background/baseline concentration of an element in known standard or average upper continental crustal concentration (Rudnick and Gao, 2003). The upper continental crust concentrations of elements were taken as baseline and background values. ER $>1$ or $<1$ means enrichment or depletion of an element relative to average crustal concentration.

Major Element Geochemistry: In Table 1, $\mathrm{SiO}_{2}$ has mean values of $75.71 \mathrm{wt}$. \%, which is higher than its average concentrations in the upper continental crust. $\mathrm{SiO}_{2}$ is the dominant major oxide element with 71.40 - 81.61 wt. $\%$, and followed by $\mathrm{Al}_{2} \mathrm{O}_{3}$ (7.01 - 12.97 wt. \%), $\mathrm{K}_{2} \mathrm{O}$ (2.36 - 3.00 wt. \%.), $\mathrm{MgO}$ (1.32 - 2.06 wt. \%), $\mathrm{Fe}_{2} \mathrm{O}_{3}\left(1.20-5.44\right.$ wt. \%) and $\mathrm{TiO}_{2}(0.69$ 2.14 wt. \%). $\mathrm{SiO}_{2}$ concentration is indicative of silica-rich source rock for the stream sediments. The values are high in SL1, SL3, SL5 and SL6. The high silica contents in comparison to alumina and alkalis concentrations reflection the prevalence of quartz relative to feldspar, mafic, carbonate and clay minerals in the sediments. Next to $\mathrm{SiO}_{2}$ is $\mathrm{Al}$ concentration, which is indicative of the disintegration of aluminosilicate minerals such as feldspar and micas. The average concentrations of $\mathrm{Al}_{2} \mathrm{O}_{3}$ in study area are slightly higher than the baseline concentration in the upper continental crust. $\mathrm{Al}_{2} \mathrm{O}_{3}$ values are high in SL1 to SL5. Additionally, $\mathrm{K}_{2} \mathrm{O}, \quad \mathrm{Fe}_{2} \mathrm{O}_{3}, \quad \mathrm{TiO}_{2}$, and $\mathrm{MgO}$ have average concentrations of 2.82 wt. \%, 1.73 wt. \%, 1.62 wt. \%, and $2.82 \mathrm{wt} . \%$, respectively which are higher than their average crustal concentrations with the exception of $\mathrm{K}_{2} \mathrm{O}$ and $\mathrm{Fe}_{2} \mathrm{O}_{3}$. The highest 
concentration values of $\mathrm{Fe}_{2} \mathrm{O}_{3}$ were recorded in SL2 indicated sediments rich in iron-bearing minerals. The lowest concentration values of $\mathrm{Fe}_{2} \mathrm{O}_{3}$ (1.20 wt. $\%$ ) were found in SL6.On the other hand, $\mathrm{CaO}, \mathrm{MnO}$, $\mathrm{Na}_{2} \mathrm{O}$ and have average concentrations of $1.50 \mathrm{wt}$. \%, 0.11 wt. $\%$ and 1.60 wt. $\%$, respectively, which are lower than their average crustal concentrations The computed CIA values for Ogbagha river sediments have range of 51.47 to 70.72 with average of 65.44 .
The CIA values for the study area are indicative of sediments in which complete chemical weathering took place with the resultant decomposition of feldspar and mica from the country rocks that in turn contributed to the enrichment of $\mathrm{SiO}_{2}$ and reduction in the concentration values of $\mathrm{CaO}, \mathrm{K}_{2} \mathrm{O}$ and $\mathrm{Na}_{2} \mathrm{O}$. The CIA values of $\mathrm{SiO}_{2}$ are indicative of silica-rich source rocks such as granite gneisses, calc-gneisses or pegmatites which abound in the study area.

Table 1: Major Oxides Geochemical Result of Samples from the Study Area in Weight \%

\begin{tabular}{|c|c|c|c|c|c|c|c|c|c|c|c|}
\hline \multirow[t]{2}{*}{ Oxides } & \multicolumn{6}{|c|}{ Sample Locations } & \multirow[t]{2}{*}{ Min. } & \multirow[t]{2}{*}{ Max. } & \multirow[t]{2}{*}{ Mean } & \multirow[t]{2}{*}{ Median } & \multirow{2}{*}{$\begin{array}{l}\text { Standard } \\
\text { Deviation }\end{array}$} \\
\hline & SL1 & SL2 & SL3 & SL4 & SL5 & SL6 & & & & & \\
\hline $\mathrm{SiO}_{2}$ & 75.13 & 71.4 & 75.66 & 74.82 & 75.61 & 81.61 & 71.4 & 81.61 & 75.71 & 75.37 & 7.38 \\
\hline $\mathrm{TiO}_{2}$ & 1.96 & 1.89 & 1.83 & 2.14 & 1.84 & 0.69 & 0.69 & 2.14 & 1.73 & 1.87 & 1.16 \\
\hline $\mathbf{A l}_{2} \mathbf{O}_{3}$ & 12.21 & 12.97 & 12.00 & 12.34 & 12.85 & 7.01 & 7.01 & 12.97 & 11.56 & 12.28 & 5.06 \\
\hline $\mathrm{Fe}_{2} \mathrm{O}_{3}$ & 2.44 & 5.44 & 1.98 & 2.34 & 2.00 & 1.20 & 1.20 & 5.44 & 2.57 & 2.32 & 1.69 \\
\hline MgO & 1.62 & 2.06 & 1.49 & 1.51 & 1.32 & 1.73 & 1.32 & 2.06 & 1.62 & 1.57 & 0.57 \\
\hline $\mathrm{CaO}$ & 1.22 & 1.54 & 1.57 & 1.43 & 1.54 & 1.69 & 1.22 & 1.69 & 1.50 & 1.54 & 0.36 \\
\hline $\mathbf{K}_{2} \mathbf{O}$ & 2.54 & 2.36 & 3.00 & 2.86 & 2.99 & 3.18 & 2.36 & 3.00 & 2.82 & 2.93 & 0.69 \\
\hline $\mathrm{Na}_{2} \mathrm{O}$ & 1.83 & 1.47 & 1.55 & 1.62 & 1.38 & 1.74 & 1.38 & 1.83 & 1.60 & 1.59 & 0.38 \\
\hline MnO & 0.10 & 0.16 & 0.14 & 0.11 & 0.10 & 0.07 & 0.07 & 0.16 & 0.11 & 0.11 & 0.07 \\
\hline $\mathbf{P}_{2} \mathbf{0}_{5}$ & 0.04 & 0.03 & 0.01 & 0.02 & 0.02 & 0.06 & 0.01 & 0.06 & 0.03 & 0.025 & 0.04 \\
\hline LOI & 0.91 & 0.68 & 0.72 & 0.81 & 0.83 & 1.02 & 0.68 & 0.91 & 0.83 & 0.82 & 0.28 \\
\hline
\end{tabular}

Table 2: Trace Elements Geochemical Result of Samples from the Study Area in ppm Units

\begin{tabular}{|c|c|c|c|c|c|c|c|c|c|c|c|}
\hline \multirow{2}{*}{$\begin{array}{l}\text { Trace } \\
\text { Elements }\end{array}$} & \multicolumn{6}{|c|}{ Sample Locations } & \multirow[t]{2}{*}{ Min. } & \multirow[t]{2}{*}{ Max. } & \multirow[t]{2}{*}{ Mean } & \multirow[t]{2}{*}{ Median } & \multirow{2}{*}{$\begin{array}{l}\text { Standard } \\
\text { Deviation }\end{array}$} \\
\hline & SL1 & SL2 & SL3 & SL4 & SL5 & SL6 & & & & & \\
\hline $\mathbf{A g}$ & 2.10 & 1.42 & 2.20 & 2.60 & 2.00 & 2.50 & 1.42 & 2.60 & 2.14 & 2.15 & 0.94 \\
\hline As & 15.00 & 7.00 & 9.00 & 12.00 & 17.00 & 29.00 & 7.00 & 29.00 & 14.83 & 13.50 & 17.57 \\
\hline Au & 16.90 & 9.30 & 15.60 & 15.80 & 19.10 & 8.60 & 8.60 & 19.10 & 14.22 & 15.70 & 9.55 \\
\hline Ba & 1,137 & 1,400 & 1,224 & 1,006 & 889.0 & 2,840 & 889.0 & 2,840 & 1,416 & $1,180.5$ & $1,608.9$ \\
\hline Be & 12.00 & 16.00 & 14.00 & 12.00 & 19.00 & 31.00 & 12.00 & 31.00 & 17.33 & 15.00 & 16.10 \\
\hline Bi & 1.20 & 0.80 & 103.0 & 1.50 & 1.20 & 1.80 & 0.80 & 103.0 & 18.25 & 1.35 & 92.84 \\
\hline Co & 7.00 & 4.00 & 9.00 & 8.00 & 5.00 & 9.00 & 4.00 & 9.00 & 7.00 & 7.50 & 4.69 \\
\hline $\mathrm{Cr}$ & 9.40 & 5.00 & 8.00 & 8.80 & 11.00 & 9.00 & 5.00 & 11.00 & 8.53 & 8.90 & 4.46 \\
\hline Cs & 1.70 & 0.80 & 1.40 & 1.60 & 1.00 & 2.00 & 0.80 & 1.70 & 1.42 & 1.50 & 1.00 \\
\hline $\mathrm{Cu}$ & 94.00 & 37.00 & 102.0 & 88.00 & 102.0 & 40.00 & 37.00 & 102.0 & 77.17 & 91.00 & 68.04 \\
\hline $\mathbf{G a}$ & 16.00 & 11.00 & 14.00 & 18.00 & 24.00 & 30.00 & 11.00 & 30.00 & 18.83 & 17.00 & 15.65 \\
\hline Hf & 7.00 & 4.00 & 6.00 & 9.00 & 13.00 & 15.00 & 4.00 & 15.00 & 9.00 & 8.0 & 9.49 \\
\hline In & 90.00 & 346.0 & 83.00 & 94.00 & 11.00 & 12.00 & 11.00 & 346.0 & 106.00 & 86.50 & 394.86 \\
\hline Ir & 174.00 & 162.0 & 168.0 & 180.0 & 91.00 & 37.00 & 37.00 & 180.0 & 135.33 & 165.00 & 129.78 \\
\hline Nb & 13.00 & 9.00 & 9.00 & 12.00 & 210.0 & 162.0 & 9.00 & 210.0 & 69.17 & 12.50 & 205.22 \\
\hline $\mathrm{Ni}$ & 7.00 & 6.00 & 5.00 & 9.00 & 13.00 & 8.00 & 5.00 & 13.00 & 8.00 & 7.50 & 6.32 \\
\hline $\mathbf{P b}$ & 16.00 & 22.00 & 14.00 & 18.00 & 4.00 & 6.00 & 4.00 & 22.0 & 13.33 & 15.00 & 15.66 \\
\hline $\mathbf{R b}$ & 190.00 & 320.0 & 240.0 & 210.0 & 9.00 & 10.00 & 9.00 & 320.0 & 163.17 & 200.00 & 243.41 \\
\hline $\mathbf{R e}$ & 184.00 & 248.0 & 172.0 & 200.0 & 180.0 & 85.00 & 85.00 & 248.0 & 178.17 & 182.00 & 118.76 \\
\hline Sb & 2.6 .00 & 1.40 & 2.40 & 2.9 .00 & 192.0 & 220.0 & 1.40 & 220.0 & 70.22 & 2.75 & 226.81 \\
\hline Sn & 38.00 & 18.00 & 29.00 & 41.00 & 2.40 & 2.40 & 2.40 & 41.0 & 21.80 & 23.50 & 32.77 \\
\hline $\mathrm{Sr}$ & 510.00 & 160.0 & 615.0 & 420.0 & 35.00 & 30.00 & 30.00 & 615.0 & 295.00 & 290.00 & 565.95 \\
\hline Ta & 4.00 & 5.00 & 7.00 & 6.00 & 299.0 & 210.0 & 4.00 & 299.0 & 88.50 & 6.50 & 388.48 \\
\hline Th & 5.00 & 4.00 & 4.00 & 7.00 & 2.60 & 2.80 & 2.60 & 7.00 & 4.23 & 4.50 & 4.02 \\
\hline TI & 0.20 & 0.40 & 0.30 & 0.40 & 7.00 & 2.00 & 0.20 & 7.00 & 1.72 & 0.40 & 5.83 \\
\hline $\mathbf{U}$ & 2.00 & 3.00 & 4.00 & 3.00 & 0.50 & 0.40 & 0.40 & 4.00 & 2.15 & 2.50 & 3.27 \\
\hline $\mathbf{V}$ & 29.00 & 38.00 & 22.00 & 32.00 & 7.00 & 2.00 & 2.00 & 38.00 & 21.70 & 25.50 & 32.08 \\
\hline $\mathbf{W}$ & 2.70 & 2.40 & 2.3 .00 & 2.50 & 19.00 & 17.00 & 2.30 & 19.00 & 7.65 & 2.60 & 17.98 \\
\hline $\mathrm{Zr}$ & 3,146 & 1,826 & 3,012 & 2,994 & 2.80 & 2.50 & 2.50 & 3,146 & 1830.55 & $2,410.00$ & $3,338.30$ \\
\hline
\end{tabular}

Trace Element Geochemistry: In Table 3, the trace elements geochemical result revealed that $\mathrm{Zr}, \mathrm{Ba}, \mathrm{Sr}$, $\mathrm{Re}, \mathrm{Rb}, \mathrm{Ir}, \mathrm{Au}$, etc. have higher concentrations than the other trace elements in the samples. The histogram plot of the distribution of these elements against their mean values is shown in Figure 2. Zr has the highest concentration with mean values of $1,830.55 \mathrm{ppm}$ in comparison to its average crustal baseline concentration. $\mathrm{Zr}$ has concentration values that range from $2.5 \mathrm{ppm}$ to $3,146 \mathrm{ppm}$ with its highest values in SL1. The high concentration values of $\mathrm{Zr}$ are indicative of complete chemical weathering of the source rocks. Ba values range from $(889-2$, 840 ppm) with the highest Ba content in SL1. The mean concentration values of $1,416 \mathrm{ppm}$ for $\mathrm{Ba}$ are very high in comparison to its average crustal baseline concentration. Sr concentration values range from $(30.00-615.00 \mathrm{ppm})$ and the highest $\mathrm{Sr}$ 
concentration values are in SL3 and less than its average upper continental crustal concentration. Re concentration values range from $(85.00-248.00$ ppm) with the highest $\mathrm{Re}$ concentration values in $\mathrm{SL2}$. $\mathrm{Rb}$ concentration values range from $(9,00-$ $320.00 \mathrm{ppm}$ ) with highest $\mathrm{Rb}$ concentration values in SL2 and higher than its average upper continental crustal concentration values. Ir values range from $(37.00-180.00 \mathrm{ppm})$ with the highest Ir concentration in SL4. In concentration values range from $(11.00-346.00 \mathrm{ppm}) . \mathrm{Cu}$ concentration values range from $(37.00-102.00 \mathrm{ppm})$. Sb concentration values range from $(1.40-220.00 \mathrm{ppm})$. The average concentration of $\mathrm{In}, \mathrm{Rb}, \mathrm{Cu}$ and $\mathrm{Sb}$ are higher than their average crustal concentration values. The pathfinder elements such as $\mathrm{As}, \mathrm{Sb}, \mathrm{Cu}, \mathrm{Pb}, \mathrm{Ag}$, etc. are good indicators of gold mineralisation in the study area. There is small scale artisanal gold mining activities taking place in the study area. As $(7-29$ ppm, mean of $14.83 \mathrm{ppm}), \mathrm{Pb}$ (4 - $22 \mathrm{ppm}$, mean of $13.33)$ and $\mathrm{Au}(8.60-19.10 \mathrm{ppm}$ with mean of 14.44 ppm).

Table 3: Results of Geochemical Analysis of Samples with Major Oxide in weight percentages and Trace Elements in ppm in comparison to published Upper Crust Concentrations in ppm $(\mathrm{n}=10)$

\begin{tabular}{|c|c|c|c|c|c|c|c|c|}
\hline \multirow[t]{2}{*}{ Oxide/Element } & \multicolumn{4}{|c|}{ This Study } & \multicolumn{4}{|c|}{ Upper Continent Crust } \\
\hline & Min. & Max. & Mean & $\begin{array}{l}\text { Std. } \\
\text { Dev. }\end{array}$ & $\bar{A}$ & $\mathbf{B}$ & $\mathbf{C}$ & $\mathbf{D}$ \\
\hline $\mathrm{SiO}_{2}$ & 71.4 & 81.61 & 75.71 & 7.38 & 67.97 & 65.89 & 66.80 & 66.62 \\
\hline $\mathrm{TiO}_{2}$ & 0.69 & 2.14 & 1.73 & 1.16 & 0.67 & 0.50 & 0.64 & 0.64 \\
\hline $\mathrm{Al}_{2} \mathrm{O}_{3}$ & 7.01 & 12.97 & 11.56 & 5.06 & 14.17 & 15.17 & 15.05 & 15.40 \\
\hline $\mathrm{Fe}_{2} \mathrm{O}_{3}$ & 1.20 & 5.44 & 2.57 & 1.69 & 5.33 & 4.49 & 4.09 & 5.04 \\
\hline $\mathrm{CaO}$ & 1.22 & 1.69 & 1.50 & 0.57 & 3.44 & 4.19 & 4.24 & 3.59 \\
\hline MgO & 2.36 & 3.00 & 2.82 & 0.36 & 2.62 & 2.20 & 2.30 & 2.48 \\
\hline $\mathbf{K}_{2} \mathbf{O}$ & 1.38 & 1.83 & 1.60 & 0.69 & 2.68 & 3.39 & 3.19 & 2.80 \\
\hline $\mathrm{Na}_{2} \mathrm{O}$ & 0.07 & 0.16 & 0.11 & 0.38 & 2.86 & 3.89 & 3.56 & 3.27 \\
\hline MnO & 0.01 & 0.06 & 0.03 & 0.07 & 0.10 & 0.07 & 0.07 & 0.10 \\
\hline $\mathrm{SO}_{3}$ & 0.68 & 0.91 & 0.83 & 0.04 & - & - & - & - \\
\hline LOI & 2.36 & 3.00 & 2.82 & 0.28 & - & - & - & - \\
\hline Au & 8.60 & 19.10 & 14.22 & 9.55 & 1.24 & 1.80 & - & 1.50 \\
\hline $\mathbf{V}$ & 2.00 & 38.00 & 21.70 & 32.08 & 98.00 & 107.00 & 53.00 & 97.00 \\
\hline $\mathrm{Cr}$ & 5.00 & 11.00 & 8.53 & 4.46 & 80.00 & 85.00 & 35.00 & 92.00 \\
\hline $\mathbf{N i}$ & 5.00 & 13.00 & 8.00 & 6.32 & 38.00 & 44.00 & 19.00 & 47.00 \\
\hline $\mathrm{Cu}$ & 37.00 & 102.00 & 77.17 & 68.04 & 32.00 & 25.00 & 14.00 & 28.00 \\
\hline $\mathbf{B a}$ & 889.00 & 2840.00 & 1416.00 & 1608.9 & 678.00 & 550.00 & 668.00 & 624.00 \\
\hline As & 7.00 & 29.00 & 14.83 & 17.57 & 4.40 & 1.50 & 2.00 & 4.80 \\
\hline $\mathrm{Sr}$ & 30.00 & 615.00 & 295.00 & 565.95 & 266.00 & 350.00 & 316.00 & 320.00 \\
\hline $\mathbf{Z r}$ & 2.5 .00 & 3146.00 & 1830.55 & 3338.3 & 188.00 & 190.00 & 237.00 & 193.00 \\
\hline $\mathbf{R b}$ & 9.00 & 320.00 & 163.17 & 243.41 & 82.00 & 112.00 & 110.00 & 84.00 \\
\hline $\mathbf{P b}$ & 4.00 & 22.00 & 13.33 & 15.66 & 18.00 & 17.00 & 17.00 & 17.00 \\
\hline Sb & 1.40 & 220.00 & 70.22 & 226.81 & 0.30 & 0.20 & 0.31 & 0.40 \\
\hline In & 11.00 & 346.00 & 106.00 & 394.86 & - & 0.05 & 0.06 & 0.06 \\
\hline Co & 4.00 & 9.00 & 7.00 & 4.69 & 17.00 & 17.00 & 12.00 & 17.30 \\
\hline $\mathbf{N b}$ & 9.00 & 210.00 & 69.17 & 205.22 & 12.00 & 12.00 & 26.00 & 12.00 \\
\hline
\end{tabular}

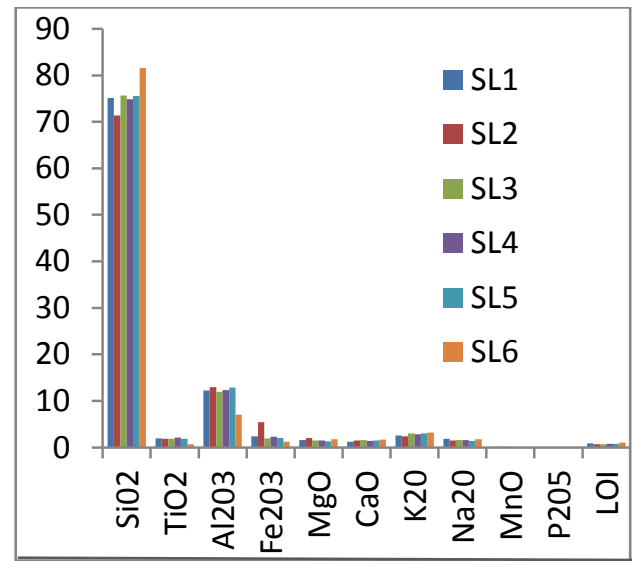

Fig. 1: Major Oxides Elements Concentration in Study Area for SL1- SL6

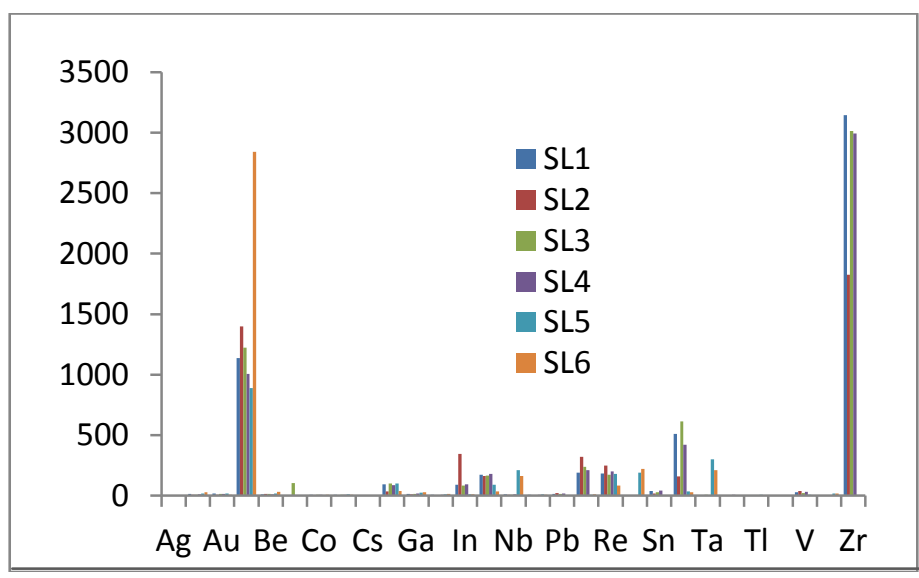

Fig. 2: Trace Elements Concentration in Study Area for SL1- SL6 
Table 4: CIA Values of different Locations in the Study Area

\begin{tabular}{cc}
\hline LOCATIONS & CIA VALUES \\
\hline SL1 & 68.59 \\
SL2 & 70.72 \\
SL3 & 66.23 \\
SL4 & 67.62 \\
SL5 & 67.98 \\
SL6 & 51.47 \\
\hline
\end{tabular}

Table 5: Enrichment Ratios for Ogbagha River Sediment Samples

\begin{tabular}{cccc} 
& \multicolumn{3}{c}{$(\mathrm{n}=10)$} \\
\hline \multirow{2}{*}{ Element } & \multicolumn{3}{c}{ Enrichment Ratios (ER) } \\
\cline { 2 - 4 } & Minimum & Maximum & Mean \\
\hline $\mathbf{A u}$ & 1.06 & 1.73 & 0.95 \\
$\mathbf{V}$ & 0.02 & 0.29 & 0.22 \\
$\mathbf{C r}$ & 0.05 & 0.12 & 0.09 \\
$\mathbf{N i}$ & 0.11 & 0.28 & 0.17 \\
$\mathbf{C u}$ & 1.32 & 3.64 & 2.76 \\
$\mathbf{B a}$ & 1.42 & 4.55 & 2.27 \\
$\mathbf{A s}$ & 1.46 & 6.04 & 3.09 \\
$\mathbf{S r}$ & 0.09 & 1.92 & 0.92 \\
$\mathbf{Z r}$ & 0.013 & 16.30 & 9.48 \\
$\mathbf{R b}$ & 0.11 & 3.81 & 1.94 \\
$\mathbf{P b}$ & 0.24 & 1.29 & 0.78 \\
$\mathbf{S b}$ & 3.50 & 500.00 & 175.55 \\
$\mathbf{I n}$ & 183.33 & $5,766.67$ & $1,766.67$ \\
$\mathbf{C o}$ & 0.23 & 0.80 & 0.40 \\
$\mathbf{N b}$ & 0.75 & 17.50 & 5.76 \\
\hline
\end{tabular}

Table 6: Index of Geoaccumulation of Trace Elements in Ogbagha River Sediments $(\mathrm{n}=10)$

\begin{tabular}{llll}
\hline Element & \multicolumn{3}{l}{ Index of Geoaccumulation $\left(\mathbf{I}_{\mathbf{g e o}}\right)$} \\
\cline { 2 - 4 } & Min. & Max. & Mean \\
\hline $\mathbf{A u}$ & 0.19 & 0.35 & -0.21 \\
$\mathbf{V}$ & 0 & 0.08 & -2.75 \\
$\mathbf{C r}$ & 0.01 & 41.39 & -1.21 \\
$\mathbf{N i}$ & 0.02 & 0.05 & -3.15 \\
$\mathbf{C u}$ & -0.184 & 0.73 & 0.88 \\
$\mathbf{B a}$ & 0.13 & 1.60 & 0.59 \\
$\mathbf{A s}$ & 0.29 & 2.01 & 1.04 \\
$\mathbf{S r}$ & 0.02 & 0.36 & -0.70 \\
$\mathbf{Z r}$ & 0 & 3.44 & 2.66 \\
$\mathbf{R b}$ & 0.02 & 1.34 & 0.37 \\
$\mathbf{P b}$ & 0.05 & -0.22 & -0.94 \\
$\mathbf{S b}$ & 0.7 & 10.43 & 6.87 \\
$\mathbf{I n}$ & 36.73 & 3.58 & 3.07 \\
$\mathbf{C o}$ & 4.52 & -1.51 & -1.89 \\
$\mathbf{N b}$ & 0.15 & 3.54 & 1.94 \\
\hline
\end{tabular}

Table 7: Class Interpretation of Index of Geoaccumulation of Trace Elements (after Muller, 1969)

\begin{tabular}{lll}
\hline $\mathbf{I}_{\text {geo }}$ Value & $\mathbf{I}_{\mathbf{g e o}}$ Class & Pollution Intensity \\
\hline $\mathbf{> 5}$ & 6 & Extremely polluted \\
$\mathbf{4 - 5}$ & 5 & Strongly to extremely polluted \\
$\mathbf{3 - 4}$ & 4 & Strongly polluted \\
$\mathbf{2 - 3}$ & 3 & Moderately to Strongly polluted \\
$\mathbf{1 - 2}$ & 2 & Moderately polluted \\
$\mathbf{0 - 1}$ & 1 & Unpolluted to moderately polluted \\
$\mathbf{0}$ & 0 & Unpolluted \\
\hline
\end{tabular}

With the exception of $\mathrm{Pb}$ that has slightly lower average concentration values than its average crustal concentration values, $\mathrm{Au}, \mathrm{Sb}$ and As have average concentration values that are very much higher than their crustal baseline concentration values. $\mathrm{Cu}$ mean concentration values of $77.17 \mathrm{ppm}$ is higher than its crustal baseline concentration values. Conversely, the mean concentration values of $\mathrm{Sr}(295 \mathrm{ppm}), \mathrm{Cr}$ (8.53 ppm), Co (7 ppm), and $\mathrm{Pb}$ (13.33 ppm) are lower than their crustal concentration baseline values. In Table 5, trace elements with ER $>1$ are In (1,766.67), Sb (175.55), Zr (9.48), Nb (5.76), As (3.09), $\mathrm{Cu}$ (2.76), Ba (2.27), Rb (1.94) and generally the samples are enriched relative to their average crustal concentration values. Conversely, trace elements with $\mathrm{ER}<1$ are $\mathrm{Au}(0.95), \mathrm{Sr}(0.92), \mathrm{Pb}$ (0.78), Co (0.40), V (0.22), Ni (0.17) and $\mathrm{Cr}$ (0.09).The mean $\mathrm{I}_{\text {geo }}$ value of 6.87 for $\mathrm{Sb}$ falls within class 6 of the Muller (1969) Scale, indicating that the sediments from the study area are extremely polluted with respect to $\mathrm{Sb}$ on scale of $\mathrm{I}_{\text {geo }}$ values $>5$. On the other hand, In has $\mathrm{I}_{\text {geo }}$ values below 4 interpreted to mean strongly polluted, showing the area has problem with respect to In contamination of the river sediments. The mean index of geoaccumulation for $\mathrm{Zr}$ is below 3 in $\mathrm{I}_{\text {geo }}$ class 3 , indicating moderately to strongly polluted. The results for $\mathrm{Nb}$ and $\mathrm{As}$ falls within class 2 of the scale, indicative of sediments that are moderately polluted. $\mathrm{Ba}, \mathrm{Cu}$, and $\mathrm{Rb}$ have mean $\mathrm{I}_{\text {geo }}$ values of $0.59,0.88$ and 0.37 , respectively that are below 1 on the scale, meaning unpolluted to moderately polluted. $\mathrm{Ni}, \mathrm{Sr}, \mathrm{Pb}, \mathrm{Co}, \mathrm{Au}, \mathrm{V}$ and $\mathrm{Cr}$ lie below class 0 , meaning unpolluted; therefore, they do not pose any environmental pollution threat in the study area. The $I_{\text {geo }}$ values indicated the absence of potentially toxic elements contamination from As, $\mathrm{Pb}, \mathrm{V}, \mathrm{Rb}, \mathrm{Ni}, \mathrm{Sr}, \mathrm{Cu}, \mathrm{Cr}, \mathrm{Co}$, etc. in the study area.

Conclusion: The Ogbagha river sediments are products of complete weathering of felsic source rock(s). Though $\mathrm{In}, \mathrm{Sb}$ and $\mathrm{Zr}$ have high pollution index level, potentially toxic elements such as Co, As, $\mathrm{Cr}, \mathrm{Cu}, \mathrm{Ni}, \mathrm{Pb}, \mathrm{Sr}, \mathrm{V}$, etc. lack environmental pollution threat in the study area. It is recommended that standard environmental remediation measures should be taken to mitigate the pollution impact of In, $\mathrm{Sb}$ and $\mathrm{Zr}$ in the study area.

\section{REFERENCES}

Atsuyuki, O (2005). Influence of surface geology and mineral deposits on the spatial distribution of elements concentration in the stream sediments of Hokkaido. Japan. J. Geochemical Exploration 86: 86-103.

Burke, KC; Dewey, JF (1972). Orogeny in Africa, In: Dessauvagie, TF; Whiteman, AJ (eds) African Geology Univ. Ibadan, pp. 583-608.

Dada, SS (2006). Proterozoic Evolution of Nigeria. In: Oshin, $\mathrm{O}$ (ed) The Basement Complex of Nigeria and its Mineral Resources Petroc. Services Ltd. Ibadan, Nigeria, pp. 29-45. 
Gao, S; Luo, TC; Zhang, BR; Zhang, HF; Han, YW; $\mathrm{Hu}$, YK; Zhao, ZD (1975). Chemical composition of the continental crust as revealed by studies in East China, Geochim. Cosmochim. Acta 62: 1959-1975.

Kautsky, G; Bolviken, N (1986). Geochemical Atlas of Northern fennoscandia Nordkalott project: Geol. Surv. Sweden, p. 19.

Muller, G (1969). Index of geoaccumulation in sediments of the Rhine River, Geo. Journal 2: 108-118.

Nesbitt, HW; Young, GM (1982). Early Proterozoic climates and plate motions inferred from major element chemistry of lutites. Nature 299: 715717.

Obaje, SO; Ugbe, FC; Akpoborie, IA; Edebiri, AO (2015). Geochemical Assessment for Gold in Sediments of Gora River in Minna area, Northcentral Nigeria. Universal Journal of Geoscience 3(1): 28-33.

Obaje, SO; Ogunyele, AC; Adeola, AO; Akingboye, AS (2019). Assessment of stream sediments pollution by potentially toxic elements in the active mining areas of Okpella. Mining-GeologyPetroleum Engineering Bulletin 34(2): 43-50. Croatia DOI: 10.17794/rgn.2019.2.5.

Ogunyele, AC;Obaje, SO;Akingboye, AS (2018). Lithostrucrural relationships and petrogenetic affinities of the Basement Complex rocks around Okpella, Southwestern Nigeria. Earth Sciences Malaysia 2(1): 29-36.

Velbel, MA (2003). Chemical weathering indices applied to weathering profiles developed on heterogeneous felsic metamorphic rocks, Chem. Geol. 202: 397-416.

Reid, JC (1993). A Geochemical Atlas of North Carolina, USA. J. Geochemical Exploration pp. 4711-4727.

Rudnick, RL; Gao, S (2003). Composition of the continental crust, in: Rudnick, RL (ed) The Crust 3, In: Holland, HD; Turekian, KK (eds), Treatise on Geochemistry. Oxford, pp. 1-64.

Taylor, SR; McLennan, SM (1985). The continental crust: Its composition and evolution. Blackwell, Oxford.
Taylor, SR; McLennan, SM (1995). The Geochemical evolution of the continental crust, Rev. Geophys. 33: 241-265.

Waziri, NM (2014). Environmental geochemistry of soils and stream sediments from Birnin-Gwari artisanal gold mining areas, North-western Nigeria, Universal Journal of Geoscience 2(1): 18-27.

Wedepohol, H (1995). The composition of the continental crust. Geochim. Cosmochim. Acta 5(59): 1217-1239. 